\title{
Chapter 6. THE INFLUENCE OF CHILDHOOD MORTALITY ON SUBSEQUENT FERTILITY DURING THE DEMO- GRAPHIC TRANSITION
}

Mark Gortfelder

\section{Introduction}

The first proponents of Demographic Transition Theory argued that a traditional society with high mortality had to compensate it with high fertility. "Any society having to face the heavy mortality characteristic of the premodern era must have high fertility to survive. All such societies are therefore ingeniously arranged to obtain the required births. Their religious doctrines, moral codes, laws, education, community customs, marriage habits, and family organizations are all focused toward maintaining high fertility," claimed Notestein (1945) in his classic article. Clearly under the traditional mortality conditions family planning as it is practiced in the $20^{\text {th }}$ century was not possible.

The first theorists took it for granted that the start of the infant and child mortality decline caused the existing, traditional reproduction system to collapse because it led to a population explosion with average yearly population growth of $1-3 \%$. Such a growth could not be sustained so a correction had to be made to the prevailing fertility behaviour, which lead to a sustained decrease of the average number of births per woman (Davis, 1945). Because of this push, fertility became a part of the calculus of the conscious choice (Coale, 1973).

This classic formulation that the mortality decline preceded the fertility decline, however, was not supported by the results of the Princeton project that set out to prove the theoretical postulations (Van de Welle, 1986). This caused some debate among demographers. This article uses micro-level data from the Family Registry of the Estonian Republic to look at this central relationship at the level of individual couples during the time of the demographic transition.

Four research questions are proposed. First, did experiencing child mortality increase the likelihood of another birth, indicating a replacement response as standard demographic theory would expect? Second, by making a distinction between women born 1860-79 and those born 
1880-99 we ask whether the replacement effect become more pronounced as fertility limitation spread among the population and became more consistent? Also, can we see a difference between urban women that were the pioneers in modernizing their reproductive life, as opposed to rural women? Third, did child mortality accelerate the timing of next birth? And fourth, did this effect grow in importance for women born later and for those living in urban areas?

\section{The mortality-fertility connection during the transition}

Much to the surprise of the scholars involved, the Princeton European Fertility Project did not support the intuitive and theoretically established understanding of the fertility transition as a necessary response by families to the infant and child mortality decline that started from the $19^{\text {th }}$ century. Knodel (1974), for example, found that in half of the administrative units of Germany marital fertility began to decrease earlier than infant mortality. Lesthaeghe (1977) had to conclude that infant mortality was not an influence on the marital fertility decline. Inconclusive or negative conclusion were also found from research done in other countries (Demeny, 1968; Livi-Bacci, 1971, 1977; Teitelbaum, 1984). "At the end of this quest", the concluding volume of the project summed it up, "we cannot report that the historical evidence confirms that the declines of infant mortality led to the decline of fertility" (Van de Walle, 1986, p. 233).

This led to some division among demographers with many seeing the classical formulation of the mortality-fertility relationship as proven false (van de Kaa, 1996). Others, however, have explained the surprising results (not only of the mortality-fertility synergy) of the Princeton project by the level of analysis and the faults of the indices used (Guinnane, Okun, Trussell, 1994; Reher, 1999). Mainly, the Princeton project used too high levels of aggregation to pick up the change in the behaviour of a considerable minority $(20 \%)$ and used data from censuses that created a cross-sectional observation. Also, they used infant mortality as the mortality indicator, while historical research has shown that it was in fact child mortality (1-4-year-olds) that started to improve earlier. ${ }^{1}$ Even Ansley Coale still held on to this idea in the concluding volume that traditional societies developed customs that promoted moderately high fertility to safeguard against extinction and that fertility did react to the revolutionary decline of mortality (Coale, 1986).

${ }^{1}$ The Princeton project in its concluding volume (Van de Welle 1986: 206-209) makes an overview and addresses these arguments. 
Chesnais emphasized that the decline of mortality was very gradual and started already from the $18^{\text {th }}$ century with the decrease of the virulence of certain infectious diseases. He also concluded that although at a local level there have been cases when fertility decline precedes that of early-life mortality, there are no cases, where this has been true at the national level and that on average, European mortality decline preceded fertility decline by 40 years (Chesnais, 1992, p. 140-148). Recent scholarship using macro-data has supported the classical understanding of the importance of decreases in early-life mortality for the fertility decline (Sánchez-Barricarte, 2017, 2018).

After the Princeton Project a wave of individual-level data gathering and analyses has developed that aims to bring a more detailed look into the period of the transition. For the most part, however, child survival has been a controlling variable and the real focus was on other research questions (Alter, Oris, Tyurin, 2007; Bengtsson, Dribe, 2006; Kolk, 2011; Van Poppel et al., 2012; Van Bavel, 2003, 2004), which means that some issues remained unresolved. An emphasis on the changing causal effect is missing and mostly the survival status of only the last child has been included.

As early-life mortality became rarer and parents adjusted their fertility accordingly, the effect on the risk of having another birth should have increased and this we can interpret as a strengthening of rational decision-making regarding reproductive life. This result has been found in some studies that have looked at the change of this relationship during the transition (Knodel, 1982; Reher, Sanz-Gimeno, 2007; Reher et al., 2017; Reher, Sandström, 2015). Reher and Sanz-Gimeno (2007) have also looked at urban/rural differences based on occupation. All of these studies have been conducted on small datasets from one or a few localities, not national data, which raises questions about representativeness.

The results of the Princeton project have suggested that more thought should be given to the complex relationship of mortality and fertility. The impact of early-life mortality on subsequent fertility of the mother is layered (Palloni, Rafalimanana, 1999; Knodel, 1982). First there is a pure physiological effect, if the child that died was an infant. An infant death means an end to breast-feeding, which leads to a quicker return to fecundity. The effect could also be there if breast-feeding ends without infant death in societal contexts, where mothers stopped breastfeeding early, which was not the case in Estonia (Rammul, 19281938). This physiological effect does not influence the hazard for next birth, but the timing of the next birth, and is powerful only when family 
limitation is weak or non-existent.

The second mechanism, replacement, refers to deliberate attempts to "replace" an existing and desired child who dies, in order to meet parity-specific (net) fertility goals. The replacement strategy raises overall fertility and should be most evident if parity-specific family limitation is exercised more consistently and widely in the population. Replacement should also influence the timing. It should lead to a shorter interval, especially if the mother is nearing menopause. However, child mortality may also lead to a need for physical and emotional healing and/or to wait for a better economic situation and thus may have an opposite effect at times.

The third mechanism, hoarding (insurance), refers to the practice of bearing a number of children above the desired family size to insure against likely future losses. This mechanism is, however, difficult to measure. First, the insurance strategy depends on an individual couple's adjustment to actual and perceived child mortality experiences in the surroundings and such perceptions are impossible to verify. Second, because hoarding is spread over the entire reproductive career of a couple the resulting association of mortality and fertility may require considerable time lags to be visible and detectable, both in terms of overall propensity and timing.

\section{Data and study population}

The Family Registry of the Estonian Republic is an individualbased historic population registry. It was kept from $1926^{2}$ to 1949 by the lowest-level local governments (towns and boroughs) on all its residents who were Estonian citizens. It is national, although for those municipalities where there was fighting during the Second World War some or all of the registry books were destroyed. ${ }^{3}$ The Registry was computerised $^{4}$ a few years ago as a cooperation between the Estonian Interior Ministry and Tallinn University. A sample of it has been studied

${ }^{2}$ In the main towns from 1920 . Before this vital event registration was conducted by religious authorities.

${ }^{3}$ Out of a total of 378 municipalities, in 35 the Registry books have been destroyed completely and in 48 partially.

${ }^{4} 1939$ local government reform created a problem of false linkages. Data insertion was not duplicated. So, if a person had an individual record then information from this was linked to the records of his or her parents. This was done using registry book and page index. With the merging of municipalities registry book number 1 in the old municipality, for example, was turned into book number 4 in the new municipality. And so false information was linked. After extra work the false linkages were limited to $6 \%$ pf all mothers. 
(Läll 2014), but the project itself was finalized in 2017 and the cleaning process was done by the author of the current article.

All local governments registered their population in a standardised way (Teder, 1939). They exchanged information if people changed their residence so there are only small problems of unregistered internal migration. Compiling the Registry was a big task for the municipalities and it is evident from comparing it with census data, that an individual record was not opened for all individuals. These problems affected mainly the elderly for whom the only vital event happening at the later stage of their lives was their own death, in which case a record was not opened.

The Registry contains retrospective information on vital events of the persons born preceding 1926. This is of high quality, since people could not solely rely on their own memory or oral family history, but documentary evidence from the church books was required. ${ }^{5}$ Still problems do exist. Due to the fact that the church books were event- and not individual-based, some events were not reregistered in the Family Registry. Looking at the proportion of illegitimate children to all children, it is evident that women were able to conceal their dead illegitimate children before 1926.

For an individual record to be opened the de facto requirement was that an individual had to live in Estonia between 1926 and 1949, which creates a significant left-truncation effect. This means that the coverage of each cohort decreases as we go back in time from 1926. For the cohorts born in 1880 s we have approximately $1 / 3$ of all births with a Family Registry individual record. The coverage ratio for mothers is of course a lot higher, since pre-marital mortality was still high. This observation scheme does create issues of selectivity and representativeness. This is first and foremost due to mortality selection - we can expect that mothers with better socioeconomic conditions who live in urban areas are overrepresented. Another issue is emigration, which was high from the 1860s to 1917 (Raun, 1986). These effects cannot be tested but they must be borne in mind.

For the study population women born between 1860 and 1899 with at least one child are chosen. The timeframe considers the coverage and selectivity issues that grow more serious for the cohorts born before 1860. The end-point is chosen so that all women under study would be over age 40 by 01.07 .1941 after which losses occur for reasons due to war and foreign occupation, which are not wholly accounted for in the

${ }^{5}$ Exceptions were made if events took place and were registered abroad and thus could not be accessed by the individuals (Teder 1939). 
registry. Only mothers with legitimate, biological, singleton live births are analysed and those with at least one data quality problem are excluded. Parity progression to the second, third, fourth and fifth child are under analysis. To see the change of the effect during the transition women are separated into two cohorts - women born 1860-79 and 1880-99. Women are observed until the next birth or age 45 . If a woman is not under observation until age 45 or her marriage ends, they are excluded.

Table 1

Dataset sizes (number of mothers)

\begin{tabular}{|c|c|c|c|c|}
\hline & $\mathbf{1 > 2}$ & $\mathbf{2}>\mathbf{3}$ & $\mathbf{3}>\mathbf{4}$ & $\mathbf{4}>\mathbf{5}$ \\
\hline Born $1860-1879$ & 40015 & 33309 & 25759 & 18719 \\
\hline Born $1880-1899$ & 67886 & 49795 & 31916 & 19291 \\
\hline
\end{tabular}

\section{Demographic transition in Estonia and its broader context}

Until the 1880s the Baltic provinces of Estland (modern-day North-Estonia), Livland (modern-day South-Estonia and North-Latvia) and Kurland (modern-day West-Latvia) enjoyed wide autonomy from the imperial government. Local political, economic and cultural life in both rural and urban areas was dominated by the Baltic Germans (5\% of the population) and their Medieval corporate institutions which were, of course, not at the forefront of building a modern statistical system. The first census in the Baltic provinces took place only in 1881 and only from that point onwards we have a fairly good understanding of national trends. A modern statistical organisation only began after the establishment of the Republic of Estonia in 1918. This is why we cannot pinpoint the start of the demographic transition exactly and cannot follow its early development in detail.

By the beginning of the $18^{\text {th }}$ century when the territory of modern Estonia went from Swedish to Russian rule the population was quite devastated due to the interplay of war, famine and disease. Still, however, as the family reconstitution research of Heldur Palli prove (1973, 1984, 1988), Estonia was west of the so-called "Hajnal line" in terms of female age at (first) marriage already during the second half of the $18^{\text {th }}$ century that saw quite substantial population growth (see 
also Chojnacka 1976). By the time of the first census in 1881, infant and child mortality had probably decreased already for decades (Katus, 2000, Vallin et al, 2017). For fertility Katus (1994a) showed that using Princeton indices Estonia experienced the 10\% decline in fertility in 1888 , the fourth country in Europe by this measure. Marital fertility was by the time of the first census lower only in Sweden and Hungary. From the first Russian imperial census in 1897 it can be ascertained that Estonia had considerably lower fertility than other Russian provinces, including the neighbouring governates (Anderson et al., 1979). Using the same data of the Registry it is estimated that in cohort view the fertility transition in Estonia began from cohorts of women born in the 1830 s or 1840s (Gortfelder, Puur, 2019)

The demographic transition in Estonia began early despite feeble economic development. Industrialisation and urbanisation only began at the end of the $19^{\text {th }}$ century and by the time of the 1897 census less than $1 / 5$ of the population lived in towns. This grew only a few percent by 1914 and reached 1/3 by the start of Soviet occupation in 1940 (Raun, 2002). This means that Estonia remained an agrarian land. Estonia, however, was at the forefront in Europe when it comes to mass literacy. By 1881 over $90 \%$ of the people were able to read and the figures for urban vs rural residents, men vs women, Baltic-Germans vs Estonians were the same by this measure. The development of literacy is based on the Lutheran Church and its teachings that emphasized the importance of reading scripture for all Christians (Kasekamp, 2010).

Spatial and social differentials in the timing of both mortality and fertility decline were considerable. Looking at the correlation of under-10 mortality and total fertility that the Family Registry and its municipalities offer, the coefficients are above 0.7. Pioneering areas were in South Estonia with its more advanced agricultural development, while the laggards were the West, Northeast and especially the Southeast, where ethnic Russians made up the majority (Katus, 1994b). Also, of course, the towns had an earlier fertility decrease. Nõges (1925) showed that in the economically and educationally most advanced county of Viljandi infant mortality declined from the $1850 \mathrm{~s}-60 \mathrm{~s}$, while fertility started to decrease there from the 1850 s and this grew to be more rapid in the $1870 \mathrm{~s} .{ }^{6}$

Infant and child mortality began to decline in rural areas as con-

${ }^{6} \mathrm{He}$ gives figures by parish starting from the 1830 s. Due to the agricultural crises in the 1840 s it is difficult to pinpoint the start of the decrease, since it caused an upswing in mortality and downswing in fertility. 
temporary observations reveal (Grosset, 1883; Huebner, 1861) and this is evident also with the Registry (Läll, 2014). These appeared among cohorts of women born in the 1860s. Contemporary studies indicate the pioneering role of the Baltic Germans in the fertility transition (Rahamägi, 1923), but this may have been more due to lower nuptiality. Germans definitely had lower infant mortality than Estonians (Jaadla, Puur, Rahu, 2017).

Thus, we conclude that ideally, we would like to extend the Family Registry back in time by 2-3 decades to be able to see the demographic transition from the pre-transition age to its end both in the pioneering areas and among the leading social groups. But still the Family Registry is an appropriate tool for detecting the changes occurring in the course of the demographic transition and therefore can be useful to study the research questions proposed here.

\section{Results}

On figure 1 the course of the decline of (overall) fertility, under-10 mortality and net fertility are shown. Due to the fact that the we cannot extend the dataset back in time, the figure does not cover the whole of the demographic transition. But the basic shape of the transition is evident and already hints at the importance of child mortality improvements for the decline of fertility. Using the fact that the population is divided by the lowest-level local government units $^{7}$ it is also easy to do a correlation test for the under-10 mortality and fertility relationship. For women born 1860-79 the correlation coefficient is 0.73 , for the $1880-99$ cohort the measure is 0.76 . Using the change of mortality and fertility the coefficient is 0.62 . This provides another proof that the relationship for both the level and change is strong.

To have a clear understanding of the effect of child mortality on subsequent fertility parity progression ratios (PPR) and median birth intervals are compared based on child survival status. PPR shows the probability of having a subsequent birth, while the median birth intervals, of course, show the timing of this next birth. In table 2 we present the main results for all women under study.

${ }^{7} 317$ municipalities were used for this exercise. 


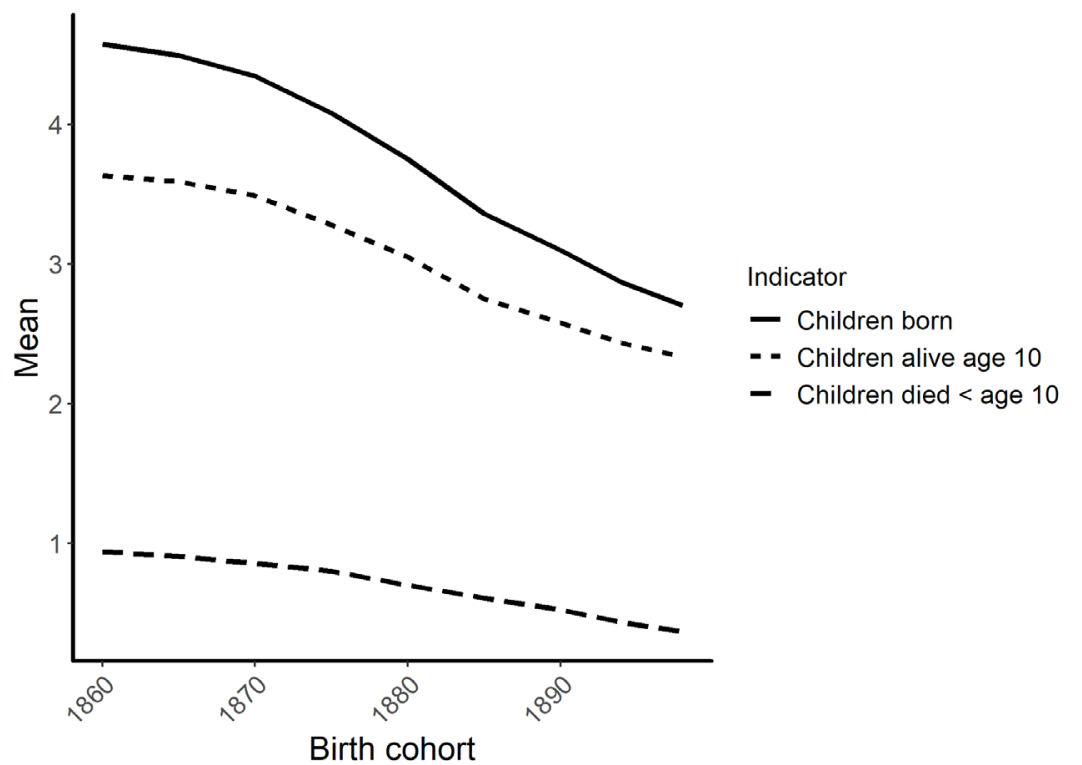

Figure 1. Mean total fertility, net fertility and children died for mothers born 1860-99

Table 2

Probability of having another birth and time to it (in months) by parity and child survival status of previous children

\begin{tabular}{|c|c|c|c|c|c|c|c|c|}
\hline \multirow{2}{*}{$\begin{array}{c}\text { Child } \\
\text { deaths }\end{array}$} & \multicolumn{4}{|c|}{ Parity progression ratios } & \multicolumn{4}{c|}{ Median birth intervals } \\
\cline { 2 - 9 } & $1>2$ & $2>3$ & $3>4$ & $4>5$ & $1>2$ & $2>3$ & $3>4$ & $4>5$ \\
\hline 0 & 0.85 & 0.75 & 0.72 & 0.70 & 21 & 24 & 25 & 24 \\
\hline 1 & 0.88 & 0.80 & 0.72 & 0.67 & 15 & 22 & 24 & 24 \\
\hline 2 & & 0.84 & 0.77 & 0.69 & & 18 & 22 & 24 \\
\hline 3 & & & 0.79 & 0.72 & & & 20 & 22 \\
\hline 4 & & & & 0.75 & & & & 23 \\
\hline Total & 0.85 & 0.77 & 0.72 & 0.69 & 20 & 24 & 24 & 24 \\
\hline
\end{tabular}

Notes: Risk set is defined as women that have had at least one birth for the $1>2$ progression, two births for the $2>3$ progression and so on. Number of deceased children are counted for the time of the conception of the next child. 
First, we will discuss the results for the PPR that are depicted on the left. Comparing the ratios by rows an obvious pattern emerges. At each parity progression women who have experienced child mortality by the time of the conception of the next child have higher likelihoods for progressing to a higher parity. For example, the progression to third birth shows that women with no child deaths had likelihood 0.75 , those with one deceased child 0.8 and those unlucky ones whose both previous children had died it was even higher 0.84 .

Reading table 2 by columns we can compare the results for the four parity progressions. It is clear that at higher parities the likelihood differences by child survival status are smaller. A selection effects probably explains this. Mothers that had already reached parity 4 did not limit their fertility as consistently as those that stopped at younger parities. Also, it has to be borne in mind that the median age for those at parity 4 is higher than at lower parities and therefore they were not as fecund. In other words, women at parity 4 had more difficulties to conceive regardless of child survival status.

Turning to median birth intervals that are depicted on the right in table 2 we can see that birth intervals were shortened by experiencing child mortality. This means that couples aimed to replace the deceased offspring quickly. However, a physiological effect also plays a part for the timing if the deceased child was an infant whose death also meant an end to breast-feeding and return to ovulation. As with PPR-s the effect of child survival decreases to non-existence for the last parity progression under study.

Table 3

Probability of having another birth and time to it (in months) by mothers' birth cohort, parity and child survival status of previous children

\begin{tabular}{|c|c|c|c|c|c|c|c|c|c|}
\hline \multirow{2}{*}{$\begin{array}{c}\text { Child } \\
\text { deaths }\end{array}$} & \multicolumn{2}{|c|}{$1>2$} & \multicolumn{2}{c|}{$2>3$} & \multicolumn{2}{c|}{$3>4$} & \multicolumn{2}{c|}{$4>5$} \\
\cline { 2 - 9 } & $1860-79$ & $1880-99$ & $1860-79$ & $1880-99$ & $1860-79$ & $1880-99$ & $1860-79$ & $1880-99$ \\
\hline \multicolumn{7}{|c|}{ Parity progression ratios } \\
\hline 0 & 0.90 & 0.82 & 0.83 & 0.70 & 0.79 & 0.66 & 0.75 & 0.65 \\
\hline 1 & 0.90 & 0.87 & 0.85 & 0.77 & 0.78 & 0.68 & 0.71 & 0.63 \\
\hline 2 & & & 0.86 & 0.83 & 0.80 & 0.74 & 0.72 & 0.66 \\
\hline 3 & & & & & 0.77 & 0.81 & 0.73 & 0.71 \\
\hline 4 & & & & & & & 0.76 & 0.73 \\
\hline Total & 0.90 & 0.82 & 0.84 & 0.72 & 0.79 & 0.67 & 0.74 & 0.65 \\
\hline
\end{tabular}


Chapter 6

\begin{tabular}{|c|c|c|c|c|c|c|c|c|c|}
\hline \multirow{2}{*}{$\begin{array}{c}\text { Child } \\
\text { deaths }\end{array}$} & \multicolumn{2}{|c|}{$1>2$} & \multicolumn{2}{c|}{$2>3$} & \multicolumn{2}{c|}{$3>4$} & \multicolumn{2}{c|}{$4>5$} \\
\cline { 2 - 9 } & $1860-79$ & $1880-99$ & $1860-79$ & $1880-99$ & $1860-79$ & $1880-99$ & $1860-79$ & $1880-99$ \\
\hline \multicolumn{7}{|c|}{ Median birth intervals } \\
\hline 0 & 21 & 21 & 24 & 25 & 25 & 25 & 24 & 24 \\
\hline 1 & 14 & 16 & 21 & 23 & 24 & 24 & 24 & 24 \\
\hline 2 & & & 17 & 19 & 21 & 22 & 23 & 24 \\
\hline 3 & & & & & 17 & 22 & 21 & 22 \\
\hline 4 & & & & & & & 23 & 23 \\
\hline Total & 20 & 21 & 23 & 24 & 24 & 25 & 24 & 24 \\
\hline
\end{tabular}

Notes: Risk set is defined as women that have had at least one birth for the $1>2$ progression, two births for the $2>3$ progression and so on. Number of deceased children are counted for the time of the conception of the next child.

We now turn to the question: how did these effects change during the transition? Table 3 presents PPRs and median birth intervals ordered also by the birth cohort of the mother. Those born 1860-79 are the cohort for which the demographic transition was in effect only in the urban areas and some agriculturally more developed rural areas. For the 1880 99 cohort the fertility transition had begun nearly everywhere and fertility levels had already decreased substantially for the pioneering areas.

We can see that in the later cohort the probabilities of next birth are lower across all parity progressions. However, a substantial change does occur during the transition. For the earlier cohort there appears to be little if any difference in the likelihood of having another birth depending on child survival status. This indicates that although at least some replacement behaviour existed, it was limited and perhaps most evident in the pioneering areas. The comparison with the later cohort shows much bigger discrepancies based on child survival status. This holds also for the last parity progression under study. Thus, we can infer that the role of human agency strengthened in fertility decision-making process. More and more couples were trying to reach parity-specific aims, which, if ruined by child mortality, they were highly motivated to mend.

With regard to birth intervals, an equivalent change is not seen. If anything for the later cohort the differences of median intervals are smaller. This is unexpected even if total change (last row) was also miniscule. Looking at median birth intervals for 5-year cohorts it is evident that unlike quantum the timing of fertility did not experience an uninterrupted linear change, but the length of birth intervals first de- 
creased for women born in the 1870s and then began to increase again for those born in the 1890s. This pattern holds also if we divide the study population by child survival status. This would indicate that the fertility transition in Estonia was mostly based on stopping rather than spacing behaviour.

Table 4

Probability of having another birth and time to it (in months) by mothers' residence, parity and child survival status of previous children

\begin{tabular}{|c|c|c|c|c|c|c|c|c|}
\hline \multirow{2}{*}{$\begin{array}{l}\text { Child } \\
\text { deaths }\end{array}$} & \multicolumn{2}{|c|}{$1>2$} & \multicolumn{2}{|c|}{$2>3$} & \multicolumn{2}{|c|}{$3>4$} & \multicolumn{2}{|c|}{$4>5$} \\
\hline & urban & rural & urban & rural & urban & rural & urban & rural \\
\hline \multicolumn{9}{|c|}{ Parity progression ratios } \\
\hline 0 & 0.78 & 0.88 & 0.66 & 0.79 & 0.64 & 0.74 & 0.64 & 0.72 \\
\hline 1 & 0.84 & 0.90 & 0.75 & 0.83 & 0.66 & 0.75 & 0.62 & 0.69 \\
\hline 2 & & & 0.80 & 0.87 & 0.72 & 0.80 & 0.64 & 0.71 \\
\hline 3 & & & & & 0.71 & 0.83 & 0.66 & 0.75 \\
\hline 4 & & & & & & & 0.67 & 0.78 \\
\hline Total & 0.79 & 0.89 & 0.69 & 0.80 & 0.66 & 0.75 & 0.64 & 0.71 \\
\hline \multicolumn{9}{|c|}{ Median birth intervals } \\
\hline 0 & 20 & 21 & 23 & 25 & 24 & 25 & 23 & 24 \\
\hline 1 & 16 & 15 & 22 & 22 & 23 & 24 & 24 & 24 \\
\hline 2 & & & 20 & 17 & 22 & 22 & 23 & 24 \\
\hline 3 & & & & & 22 & 18 & 21 & 23 \\
\hline 4 & & & & & & & 26 & 23 \\
\hline Total & 20 & 21 & 23 & 24 & 24 & 24 & 23 & 24 \\
\hline
\end{tabular}

Notes: Risk set is defined as women that have had at least one birth for the $1>2$ progression, two births for the $2>3$ progression and so on. Number of deceased children are counted for the time of the conception of the next child.

Lastly, we turn to the urban-rural comparison of the mortality-fertility synergy. Table 4 has instead of cohort the residence type of the mother as a distinction. The likelihoods of experiencing another birth are higher for rural women regardless of child survival status. However, we can see clearly that among the urban women the discrepancies based on the number of dead children are more pronounced, meaning that urban women had more modern reproductive lives. This we would expect since the urban areas were the pioneers in new fertility behaviour. 
Additionally, an extra analysis was done (not reported in here) which divided urban women into those living in the bigger towns ${ }^{8}$ and those living in the small towns. The pattern that emerged was that women living in small towns were in between the rural and big town women in their likelihoods for experiencing another birth, as expected. ${ }^{9}$

Birth intervals were only a tiny bit shorter in urban areas, indicating that what set urban women apart was their implementation of stopping strategy to control their childbearing. Looking at the differences based on number of child deaths, the impact of child fatalities is more pronounced for the rural women. This again underlines that the increasing agency was more a factor of parity-specific rather than birth timing control.

\section{Conclusion}

The results reported prove that the experience of child deaths was an important factor for parents considering whether or not to have an additional birth. For the first research question proposed, we confirm that having deceased children raised the likelihood of having another birth across the four parity progression that were under study, although the effect decreased in size for the higher progressions. The effect was significantly more pronounced for women born later and women living in urban areas. This answers in affirmative the second research question proposed. The increase of family planning during the course of the transition and among the pioneering groups made the differences in probabilities of next birth more pronounced. This confirms the classical understanding of the demographic transition, that in the traditional era behavioural replacement of dead children was not common, but as early-life mortality began to decrease, which enabled parents to start having explicit fertility goals in terms of number of children reaching adulthood, parents began to deliberately replace deceased children to achieve their goal. Experiencing child mortality also shortened the birth intervals, which was the third question proposed, although for the last parity progression under study this effect largely disappears. Finally, for the fourth research question we have to answer in the negative. The effect of child mortality on birth intervals decreased for the last cohort and was not more pronounced for the women residing in urban areas.

${ }^{8}$ Tallinn, Tartu, Narva, Pärnu.

${ }^{9}$ The picture got more complicated for the last progression, since the numbers of women get small at some child survival levels. 
From the results we can infer that even in a traditional society (in our case the earlier cohort and rural women) at least some behavioural replacement response can be detected as also others have shown (Knodel 1982; Reher et al. 2017). But the power of this effect grows a lot when couples practice modern family limitation.

\section{References}

Alter, George, Michel Oris, and Konstantin Tyurin. (2007). 'The Shape of a Fertility Transition: An Analysis of Birth Intervals in Eastern Belgium'. presented at the PAA, New York City.

Anderson, Barbara, Coale Ansley and Härm Erna. (1979). Human Fertility in Russia since the Nineteenth Century. Princeton: Princeton University Press.

Bengtsson, Tommy, and Martin Dribe. (2006). 'Deliberate Control in a Natural Fertility Population: Southern Sweden, 1766-1864'. Demography 43 (4): 727-46.

Chesnais, Jean-Claude. (1992). The Demographic Transition: Stages, Patterns and Economic Implications. Oxford: Oxford University Press.

Chojnacka, Helena. (1976). 'Nuptiality Patterns in an Agrarian Society'. Population Studies 30 (2): 203-226.

Coale, Ansley. (1973). 'The Demographic Transition Reconsidered'. International Population Conference, Liege. Oxford: Clarendon Press: 53-72.

Coale, Ansley. (1986). 'The Decline of Fertility in Europe since the Eighteenth Century as a Chapter in Demographic History'. The Decline of Fertility in Europe. New York: Population Council: 1-30.

Davis, Kingsley. (1945). 'The World Demographic Transition'. The Annals of the American Academy of Political and Social Science 237: 1-11.

Demeny, Paul. (1968). 'Early Fertility Decline in Austria-Hungary: A Lesson in Demographic Transition'. Daedalus 97 (2): 502-22.

Gortfelder, Mark, Allan Puur. (2019). 'Demograafiline nüüdisajastumine Eestis: 1850-1899 sündinud naiste emaduslugude analüüs'. Tuna: ajalookultuuri ajakiri 22 (1): 19-38.

Grosset, Ottomar. (1883). 'Biostatik der Stadt Dorpat und ihrer Landgemeinde in den Jahren 1860-1881 : Inaugural-Dissertation'. Thesis, Dorpat : Laakmann.

Guinnane, Timothy W., Barbara S. Okun, and James Trussell. (1994). 'What Do We Know About the Timing of Fertility Transitions in Europe?' Demography 31 (1): 1-20.

Huebner, Felix. (1861). 'Biostatik der Stadt Dorpat und ihrer Landgemeinde in den Jahren 1834-1859 : eine Abhandlung, welche mit Bewilligung einer Hochverordneten Medicinischen Facultät der Universität zu Dorpat zur 
Erlangung des Doctorgrades öffentlich vertheidigen wird'. Thesis, Dorpat : Laakmann.

Jaadla, Hannaliis, Allan Puur, and Kaja Rahu. (2017). 'Socioeconomic and Cultural Differentials in Mortality in a Late 19th Century Urban Setting: A Linked Records Study from Tartu, Estonia, 1897-1900'. Demographic Research 36 (1): 1-40.

Kaa, D. J. van de. (1996). 'Anchored Narratives: The Story and Findings of Half a Century of Research into the Determinants of Fertility'. Population Studies 50 (3): 389-432.

Kasekamp, Andres. (2013). The History of the Baltic Countries. London: Palgrave.

Katus, Kalev. (1994a). 'Sündimus Ja Selle Piirkondlikud Erisused Eestis Demograafilise Ülemineku Jooksul. I'. Akadeemia 6 (1): 134-49.

Katus, Kalev. (1994b). 'Sündimus Ja Selle Piirkondlikud Erisused Eestis Demograafilise Ülemineku Jooksul. II’. Akadeemia 6 (2): 365-85.

Katus, Kalev. (2000). 'Long-Term Mortality Trend in the Baltic Countries'. Trames 4 (3): 231-56.

Knodel, John. 1982. 'Child Mortality and Reproductive Behaviour in German Village Populations in the Past: A Micro-Level Analysis of the Replacement Effect'. Population Studies 36 (2): 177-200.

Knodel, John. (1974). The Decline of Fertility in Germany, 1871-1939. Princeton: Princeton University Press.

Kolk, Martin. (2011). 'Deliberate Birth Spacing in Nineteenth Century Northern Sweden'. European Journal of Population / Revue Européenne de Démographie 27 (3): 337-59.

Lesthaeghe, Ron. (1977). The Decline of Belgian Fertility, 1800-1970. Princeton: Princeton University Press.

Livi-Bacci, Massimo. (1971). A Century of Portuguese Fertility. Princeton: Princeton University Press.

Livi-Bacci, Massimo. (1977). A History of Italian Fertility during the Last Two Centuries. Princeton: Princeton University Press.

Läll, Markus. (2014). 'Fertility Transition in 19th-20th Century Estonia: An Individual Level Perspective'. Masters Thesis, Stockholm: Stockholm University.

Notestein, Frank. (1945). 'Population - The Long View'. Food for the world. Chicago: University of Chicago Press: 36-57.

Nõges, Mats. (1925). 'Rahwamuutused Wiljandi maakonnas 1801.1923. a. = Bevölkerungsbewegung im Kreise Fellin in Jahren 1801-1923 : demograafiline töö : [väitekiri]'.

Palli, Heldur. (1984). Lääne-Eesti rahvastiku struktuur ja taastootmine (Karuse 1685-1799). Tallinn: Eesti Raamat. 
Palli, Heldur. (1988). Otepää rahvastik aastail 1716-1799. Tallinn: Eesti Raamat.

Palli, Heldur. (1973). 'Rõuge rahvas XVII sajandi teisel poolel'. Ajaloolise demograafia probleeme Eestis. Tallinn: ENSV Teaduste Akadeema Ajaloo Instituut

Palloni, Alberto, and Hantamala Rafalimanana. (1999). 'The Effects of Infant Mortality on Fertility Revisited: New Evidence from Latin America'. Demography 36 (1): 41-58. https://doi.org/10.2307/2648133.

Rahamägi, Hugo. (1923). Eesti rahva sündivuse vähenemise põhjused ja teed selle nähtuse kõrvaldamiseks : sotsiaal-eetiline käsitlus. Tartu Ülikool.

Rammul, Aleksander. (1928-1938). Tervishoiulised kirjeldused. Tartu: Tartu Ülikooli Tervishoiu Instituut.

Raun, Toivo U. (1986). 'Estonian Emigration within the Russian Empire, 1860-1917’. Journal of Baltic Studies 17 (4): 350-63.

Raun, Toivo U. (2001). Estonia and the Estonians. Stanford: Hoover Institution Press.

Reher, David Sven. (1999). 'Back to the Basics: Mortality and Fertility Interactions during the Demographic Transition'. Continuity and Change 14 (1): 9-31.

Reher, David Sven, and Glenn Sandström. (2015). 'Dimensions of Rational Decision-Making during the Demographic Transition; Aranjuez (Spain) Revisited'. Historical Life Course Studies 2 (March): 20-36.

Reher, David Sven, Glenn Sandström, Alberto Sanz-Gimeno, and Frans W. A. van Poppel. (2017). 'Agency in Fertility Decisions in Western Europe During the Demographic Transition: A Comparative Perspective'. Demography 54 (1): 3-22.

Reher, David Sven, and Alberto Sanz-Gimeno. (2007). 'Rethinking Historical Reproductive Change: Insights from Longitudinal Data for a Spanish Town'. Population and Development Review 33 (4): 703-27.

Sánchez-Barricarte, Jesús J. (2017). 'Mortality-Fertility Synergies during the Demographic Transition in the Developed World'. Population Studies 71 (2): 155-70.

Sánchez-Barricarte, Jesús J. (2018). 'Historical Reproductive Patterns in Developed Countries: Aggregate-Level Perspective'. Demographic Research 38 (2): 37-94.

Teder, Tarmo. (1939). 'Perekonnaseisuametniku käsiraamat'. Tallinn: Siseministeeriumi Administratiivala Kirjastus.

Teitelbaum, Michael. (1984). The British Fertility Decline: Demographic Transition in the Crucible of the Industrial Revolution. Princeton: Princeton University Press.

Vallin, Jacques, Domantas Jasilionis \& France Meslé. (2017). 'Does a turbulent history lead to turbulent life expectancy trends? Evidence from the 
Baltic States'. Historical Methods: A Journal of Quantitative and Interdisciplinary History 50 (4): 191-209.

Van Bavel, Jan. (2003). 'Birth Spacing as a Family Strategy: Evidence from 19th Century Leuven, Belgium'. The History of the Family 8 (4): 585-604.

Van Bavel, Jan. (2004). 'Deliberate Birth Spacing before the Fertility Transition in Europe: Evidence from Nineteenth-Century Belgium'. Population Studies 58 (1): 95-107.

Van de Welle, Francine. (1986). 'Infant mortality and the European demographic transition'. The Decline of Fertility in Europe. New York: Population Council: 201-233.

Van Poppel, Frans, David Sven Reher, Alberto Sanz-Gimeno, Maria Sanchez-Dominguez, and Erik Beekink. (2012). 'Mortality Decline and Reproductive Change during the Dutch Demographic Transition: Revisiting a Traditional Debate with New Data'. Demographic Research 27 (August): 299-338. 